\title{
Small industries in developing countries
}

\author{
Jan $\mathrm{H}$. Lange \\ School of Business Leadership, University of South Africa, Pretoria
}

Paper delivered at the 'Bolts and nuts of a small
business' seminar offered by the Bophuthatswana
Chamber of Commerce on 27 November 1979 at
Mmabatho, Bophuthatswana

A regional development programme is set out for a developing country, using Bophuthatswana as an example. A stable society with an increasing quality of life, and creation of enough lob opportunities in the country are assumed as the primary objectives. Of the various alternative approaches to creating employment opportunities - agriculture, wholesale and retall trade, construction of infrastructure, and large scale and small industry - it appears that labour-intensive small industries can achieve employment objectives at the lowest cost to the economy. This approach, which also develops entrepreneurship and organizational talent, is recommended as having economic, social and political advantages. The roles of small scale industrial entrepreneurs in developed and in developing countries are contrasted, the major problems in the latter being the ability to identify potentially profitable projects for export, and the ability to market in neighbouring countries. The proposed development strategy would require a new specialized development agency in South Africa, collaborating closely with the developing states's own development agency, and both of them assisting entrepreneurs to identify projects with potential.

S. Afr. J. Bus. Mgmt 1980, 11: 1 - 4

'n Streeksontwikkelingsprogram vir 'n ontwikkelende land word beskryf met Bophuthatswana as voorbeeld. 'n Stabiele gemeenskap met toenemende lewensgehalte, en skepping van genoeg werksgeleenthede in die land word as die primêre doelwitte aanvaar. Van verskeie alternatiewe benaderings tot werkgeleentheidskepping - landbou, klein- en groothandel, konstruksie van infrastruktuur, en groot en klein nywerhede blyk dit dat klein nywerhede werkverskaffingsdoe/witte teen die laagste koste aan die ekonomie kan bereik. Dié benadering, wat ook entrepreneurskap en bestuurstalent ontwikkel, word aanbeveel omdat dit naas ekonomiese, ook sosiale en politiese voordele het. Dle rolle van klein nyweraars in ontwikkelde en ontwikkelende lande word gekontrasteer, en die belangrikste probleme vir laasgenoemde is die vermoe om potensieel winsgewende projekte vir uitvoer te identifiseer, en die vermoe om in buurlande te bemark. Die voorgestelde ontwikkelingstrategie sou ' $n$ nuwe gespesialiseerde ontwikke. lingsagentskap in Suid-Afrika vereis, wat nou saamwerk met die ontwikkelende staat se ontwikkelingskorporasie, terwyl beide entrepreneurs help om projekte met potensiaal te iden. tifiseer.

S.Afr. Tydskr. Bedryfsl. 1980, 11: $1-4$

\author{
J.H. Lange \\ Senior Researcher, School of Business Leadership, University of South Africa, \\ P.O. Box 392, Pretoria 0001, South Africa
}

For a paper of this nature, my point of departure, as a regional scientist, is a specific regional or interregional economic development goal or objective, and the ways and means of achieving that objective. For the purposes of this paper, I assumed that Bophuthatswana's primary development objective is to be a stable society with an ever-increasing quality of life. Translated into operational development terms, this means the creation of enough employment opportunities within the country's borders to accommodate its growing population.

\section{Creating employment opportunities: Alternative ap. proaches}

Once 'maximizing employment opportunities' is identified as a country's or a region's development objective, the problem reduces to that of minimizing the economic cost of that goal. This suggests that that programme or combination of programmes which offers the largest expected increase in employment opportunities, given the country's available development budget, will be adopted. Against this background the pros and cons of alternative programmes can be considered.

\section{Agricultural programmes}

Studies carried out by the International Labour Organization suggest that agricultural programmes alone cannot provide enough employment opportunities for the unemployed and under-employed of developing countries.'

Another fact about agricultural programmes, though this is only important for Bophuthatswana in the long term, is that the more effective agricultural production becomes, the less labour is required.

\section{Wholesale and retail activities}

In an open developing economy (such as that of Bophuthatswana) in close proximity to a developed economy (such as that of the Republic of South Africa), the promotion of wholesale and retail activities will tend to facilitate the outflow of funds from the developing economy, and therefore tend to have an adverse effect on the economic base multiplier of the developing economy. Development policy should therefore be designed to stimulate trade activities in Bophuthatswana just to the point where it will not be necessary for people to spend their income on the South African side of your country's borders. 


\section{Construction of infrastructure}

Rosenstein-Rodan has pointed out that the number of permanent jobs created by the building of infrastructure is a mere fraction of the additional jobs created during the construction phases of such projects. ${ }^{2}$ Infrastructure construction should therefore not be relied upon exclusively to generate increasing numbers of permanent jobs.

\section{Industry}

\section{Large scale industry}

If developing countries are considering programmes to attract large scale industry as a means of maximizing employment opportunities, they must realize:

- that large scale industry requires management of a high degree of sophistication;

o that large amounts of money will be involved; and

- that, as far as their efforts to attract such industry are concerned, they are in competition with a large number of other developing countries as well as countries like Korea and Hong Kong, and several of the Southern States of the USA.

\section{Small scale industry}

A United Nations study group noted the following about small industries: 'If the policy criterium is to increase employment in depressed areas, then labour-intensive small industries can achieve the socially desirable objective of short-run employment maximization - at the lowest cost to the national economy'. ${ }^{3}$ A recommendation that Bophuthatswana focuses its development efforts on small scale industry might come as a disappointment to some members of the government. A small industries programme need, however, not be inconsistent with the longer term development objectives of the country, which may include the development of larger scale industries. However, small scale industry producing modern final products for Bophuthatswana's local markets, or intermediate and final goods for markets in South Africa and beyond, are ideally suited to overcome the initial deficiencies in the economic structure of a developing country.

In many parts of the world small scale industries have played the role of seedbeds for the growth of organizational talent and entrepreneurship, and have contributed considerably to the training of labour. There are no obvious reasons why they cannot also fulfil these roles in Bophuthatswana. Small industries can tap small quantities of all types of resources that would remain untapped in their absence. For instance, in India, small scale industries have played an important role in the reorientation of entire families and communities toward the demands and requirements of an industrial society; that is to introduce industrial rhythm to an agrarian society. ${ }^{4}$

The sociological and political advantages of encouraging small scale industries include the development of a middle-class group of independent entrepreneurs, which is a desirable and much needed element in a society that values democratic self-rule. ${ }^{5}$ p.27

Other advantages of small industry development programmes include the fact that losses caused by mistaken investment or production decisions by relatively inexperienced managers, are less serious in small industries than in large scale industries. Small industry is often also the most efficient way of meeting demand when:

o the local market for a given item is limited

o where transportation costs are high

- where a highly specialized market is served, and

0 where product changes are frequent. ${ }^{6}$

Contrasts between the roles of small scale industrial entrepreneurs in developed and in developing areas

\section{Developed country}

In a developed country the entrepreneurial function boils down to the following activities:

- Identifying potentially profitable industrial projects;

- Carrying out a feasibility study on the project;

- Establishing the industry, that is:

- acquiring production equipment

- employing labour

- training labour, etc.

- Effective management of the small industry, that is:

- procurement

- production

- supervision

- quality control

- maintenance, and

- effective marketing.

\section{Developing country}

In a developing country the same entrepreneurial functions need to be carried out to ensure the success of any small industry.

Industry in an open developing country, such as Bophuthatswana, can be divided into basic industry, that is those industries serving markets across the borders of the country, and non-basic industry, that is those serving local markets. According to the time tested economic base model, the basic industries are the prime movers of the economy of an open region or of the local economy of a country.

If employment in the basic industries increases, employment in the rest of the local economy increases by a multiple, the size of which depends on the economic base multiplier of the area.

The entrepreneurial function with respect to basic industries, in a developing country, is far more complex than that with respect to non-basic industries. In the former case it requires, factors such as the ability to identify potentially profitable projects in markets across the borders of Bophuthatswana, and the ability to market in (that is to export effectively to) those markets.

It is highly unlikely that more than a few people with the ability to carry out all the entrepreneurial functions will be found in Bophuthatswana. The success of a small industry development programme as a means of creating employment opportunities in Bophuthatswana, however, depends critically on the availability of entrepreneurs with the ability to establish and manage basic industries. It will therefore be necessary to design a development 
programme specifically to overcome the shortage-ofentrepreneurs-problem.

\section{A development programme to overcome the shortage-of-entrepreneurs-problem}

An effective programme to overcome the problem of a shortage of entrepreneurs with the ability to establish basic small scale industries in Bophuthatswana, will require co-operation between a specialized development agency in South Africa, the Bophuthatswana National Development Corporation and prospective entrepreneurs. The role of each of these participants in the programme will now receive our attention.

\section{A new specialized development agency in South Africa}

The South African Prime Minister, the Hon. P.W. Botha, identified in his address to South African business leaders on 22 November 1979 in Johannesburg, the 'achieve(ment) of a more equitable regional distribution of economic development in Southern Africa's p.33 as one of the goals to be pursued in a Constellation of Southern African States. To achieve this goal labour intensive small scale basic industries will have to be established inter alia in Bophuthatswana. Achievement of this goal will only be possible if certain critical services can be rendered by a specialized $R S A$ development agency to the national development corporations of states within the proposed constellation of Southern African States. These services include:

0 the development and offering for sale (to national development corporations) of labour intensive small scale industrial projects; a service which will involve:

- the identification of potentially profitable small scale industrial projects producing for South Africa industrial or consumer markets; and

- the research and development required to change capital intensive production processes, or parts thereof, ${ }^{7 p .7 f f}$ to labour intensive processes without changing the quality of the final output of the process;

- the securing of production contracts, or subcontracts, for small scale industries in the developing states from inter alia:

- the South African Director of State Purchases (the earmarking of South African Government contracts for small scale industry will require legislation along the lines of the USA legislation under which the USA Small Business Administration operates: the Armed Services Procurement Act of 1947; the Selective Services Act of 1948; the Federal Property and Administration Services Act of 1949; the Defence Production Act Amendments of 1951; and the Small Business Act of 1953);

- Armscor;

- Large scale industry in South Africa's private sector (subcontracts given by large scale industry to small scale industry in developing countries is considered one of the most effective methods of transferring industrial know-how from developed to developing countries);
- the offering of terminal facilities in the PretoriaWitwatersrand-Vereeniging area to facilitate the flow of raw materials, and finished and semifinished products in industrial parks in the developing countries and subcontract-giving industries in the PWV area;

- procurement of raw materials at favourable bulk terms in South Africa on behalf of small scale industry in the developing countries within the Constellation of States; and

o the training of industrial extention officers for the National Development Corporations of the developing countries in the Constellation of Southern African States.

\section{The developing country's National Development Corporation}

To overcome the problem of shortages of entrepreneurs with the ability to ef fectively establish and manage basic small scale industries in the developing countries, certain specialized services should be offered to prospective entrepreneurs and to established small industries by the national development corporations of the various developing countries. These activities should include:

- the establishment of industrial parks designed? ${ }^{\text {p.Sff }}$ to minimize the fixed costs and thus the risk of small scale industries locating in the parks;

- the selection of suitable candidates to be trained as small scale industry entrepreneurs (technical and commercial aspects);

- training of small scale industry entrepreneurs (the instructional programmes developed for the Reverent Leon Sullivan's OIC entrepreneurial development programmes in Philadelphia can possibly be adopted for this purpose);

- the rendering of realistic industrial financial services to small scale entrepreneurs (including crisis financing);

o the employment of suitably qualified industrial and commercial extention of ficers;

- the rendering, free of charge, of industrial and commercial extention services to small scale industry located in industrial parks.

The small scale industry development programme of which only the skeleton could be given in this paper would, in the sense that certain critical functions would be carried out by specialized development agencies, relax the strict requirements for successful entrepreneurship. It can therefore be expected that with such a programme more small industries will be established successfully in developing countries within the proposed Constellation of Southern African States.

\section{Evaluating this development proposal}

For a development strategy to be successful it must be beneficial to all the parties concerned. In conclusion it will therefore be necessary to identify the potential benefits of the development strategy proposed in this paper, as they accrue to the different participants in the strategy. 
Benefits for Bophuthatswana's small industry entrepreneurs

- It will reduce the capital required to start a new small scale industry;

- It will increase the probability of success of new industrial ventures in Bophuthatswana;

- It will enable the successful small industries to grow into large industry.

\section{Benefits for Bophuthatswana's Government and its economy}

- It will develop the latent comparative advantages of the economy of Bophuthatswana; ${ }^{5}$.33

- It will 'neutralize' the magnetic effect of the developed centres' of South Africa on Bophuthatswana's employment-seeking population; ${ }^{\text {p.34 }}$

- It will generate the purchasing power in Bophuthatswana's economy on which new nonindustrial economic activities of fering more employment opportunities, can be based; and

- It can make a substantial contribution to the development of a middle class, enjoying an everincreasing quality of life under stable government in Bophuthatswana.

\section{Benefits for the South African economy}

- It will reverse the trend towards increased capital intensity which occurred in South Africa's industrial sector since 1970;

- In so far as it will increase the labour content and reduce the capital content of South Africa's industrial output, it will make the economy less dependent on imported capital goods and protect its balance of payments during the economic upswing; and

- It will enable South African industrialists to increase their output without substantial new investment.

\section{Conclusion}

The development strategy proposed in this paper requires government activity only as a catalist, while its potential to increase employment opportunities and raise the quality of life in every national state within the proposed Constellation of Southern African States, suggests largely increased opportunities for private sector activity in an enlarged Southern African regional market.
The proposed strategy has two main features: Close cooperation between development agencies (both in South Africa and in the developing national states) and individual entrepreneurs; and assistance to entrepreneurs in identifying and implementing projects with potential.

This approach should be far more effective and have more lasting results than the mere encouragement and large amounts of capital, which too frequently is the favourite form of aid given to developing countries.

\section{References}

1 ILO: Service for small scale industry. New series, 61, Geneva, 1961, p.20.

2 ROSENSTEIN-RODAN, P.N. How to industrialize an underdeveloped area. In: Regional economic planning techniques of analysis for less developed areas. (ed.) Isard, W. Organization for Europene Economic Co-operation, 1960, p.205.

3 United Nations, ID Conf. 12 (1967), p.47.

4 ROBINSON, H.E. Productivity and small scale industry. Nat. Productivity Council, Special Issue, New Delhi, India, 1962, p.847.

5 This accounts for the special emphasis placed on small industry programmes by the Hon. P.W. Botha in his address to South African business leaders on the proposed Constellation of Southern African States on 22 November 1979 in Johannesburg. Verbatum address as released by the South African Information Service in Pretoria.

6 LANGE, J.H. Programmed planning for the elimination of economic dualism in a system of cultural regions. Ph.D. Dissertation, University of Pennsylvania, Philadelphia, 1970, pp.90-91.

7 It is by no means necessary for small scale industries, or for that matter, for any industry, to handle production from the raw material to the dispatch stage of the final product. In fact, production of components by small scale industry, in the developing states within the proposed Constellation of States, on a subcontracting basis for large scale industry in South Africa, presents one of the tries. Dept of Economic and Social Affairs, United Nations, New York, 1961, pp. $1-3$.

See: LANGE, J.H. A first step towards industrialization. Southern Africa Technology Development Group, Braamfontein, July 1973.

8 The first industrial park in the United Kingdom was established in 1896, in the USA in 1899 and in Italy in 1904. The Italian Government began to promote industrial parks as a tool for the industrialization of Southern Italy in 1957. In India, the establishment of industrial parks forms one of the most important parts of their small industry programme. By 1960 a total of 120 industrial estates were occupied in India. By 1959, Puerto Rico had a network of 30 industrial parks in operation.

See: The establishment of industrial parks in under-developed countries. Dept of Economic and Social Affairs, United Nations, New York, 1961, pp.1-3. 